\title{
7 Quellen- und Literaturverzeichnis
}

\section{Archivalische Quellen}

Alexander Turnbull Library, Wellington, New Zealand

Tagebuch Lieut. Alexander B. McColl, Taranaki Company, Wellington Inf. Regt.

MSX-8204

Bundesarchiv Militärarchiv Freiburg i. Br.

$\mathrm{N} 247 / 40$

N902/7-22

RH61/1088

RH61/1802

RH61/1827

The National Archives (TNA), Kew, United Kingdom

Records of the Cabinet Office (CAB)

TNA-CAB 45/243

TNA-CAB $45 / 244$

TNA-CAB $45 / 245$

British Army War Diaries 1914-1922

TNA-W095/4288-1

\section{Literaturverzeichnis}

Addison, Paul: The Three Careers of Winston Churchill, in: Transactions of the Royal Historical Society 11 (2001), S. 183-199.

Ahmad, Feroz: The Young Turks: The Committee of Union and Progress in Turkish Politics 1908-1914. Oxford 1969.

Aksakal, Mustafa: The Ottoman Road to War in 1914. The Ottoman Empire and the First World War. Cambridge et al. 2008.

Allen, Brooke: More than the Sum of His Parts: The Enigma of Winston Churchill, in: The Hudson Review 55:2 (2002), S. $312-318$.

Alvarez, Jose E.: Between Gallipoli and D-Day: Alhucemas, 1925, in: The Journal of Military History 63:1 (1999), S. 75-98.

A Man of the Tenth (i.e. A. R. Perry): The Landing, in: The Anzac Book. Written and Illustrated in Gallipoli by the The Men of Anzac. London et al. 1916, S. 1-6.

Andurain, Julie de: Le général Gouraud, chef du corps expéditionnaire des Dardanelles en 1915, in: Revue historique des armées 258 (2010), http://rha.revues.org/6921 (Letzter Zugriff am 15.7.2017).

Angelow, Jürgen: Der Weg in die Urkatastrophe. Der Zerfall des alten Europa 1900-1914, Deutsche Geschichte im 20. Jahrhundert, Bd. 2. Berlin 2010.

Ә OpenAccess. ( 2020 Frank Jacob, publiziert von De Gruyter. (cc) BY-NC-ND Dieses Werk ist lizenziert unter der Creative Commons Attribution-NonCommercial-NoDerivatives 4.0 License. 
Armstrong, Harold C.: Grey Wolf, Mustafa Kemal: An Intimate Study of a Dictator. Freeport, NY 1972 [1932].

Arnett, Jeffrey: Winston Churchill, the Quintessential Sensation Seeker, in: Political Psychology 12:4 (1991), S. 609-621.

Ashmead-Bartlett, Ellis: The Uncensored Dardanelles. London 1920.

Bauer, Franz J.: Das „lange“ 19. Jahrhundert. Profil einer Epoche. Stuttgart 2004.

Baxter, Colin F.: Winston Churchill: Military Strategist? in: Military Affairs 47:1 (1983), S. 7-10.

BBC: Gallipoli Centenary Marked by Queen and UK Leaders. 25. April 2025,

https://www.bbc.com/news/uk-32460946 (10.08. 2020).

Bean, C. E. W.: Gallipoli Mission. Canberra 1948.

Bean, C. E. W.: The Official History of Australia in the War of 1914-1918, Bd. 2: The Story of ANZAC from 4 May, 1915, to the Evacuation of the Gallipoli Peninsula. Sydney 1941.

Ben-Moshe, Tuvia: Winston Churchill and the „Second Front“: A Reappraisal, in: The Journal of Modern History 62:3 (1990), S. 503-537.

Beşikçi, Mehmet. Mobilizing Military Labor in the Age of Total War: Ottoman Conscription before and during the Great War, in: Zürcher, Erik-Jan (Hrsg.): Fighting for a Living: A Comparative Study of Military Labour 1500-2000. Amsterdam 2014, 547-580.

Besikçi, Mehmet: The Ottoman Mobilization of Manpower in the First World War: Between Voluntarism and Resistance. Leiden 2012.

Birdwood, W. R.: Introduction, in: The Anzac Book. Written and Illustrated in Gallipoli by the The Men of Anzac. London et al. 1916, ix-x.

Bittner, Donald F.: Britannia's Sheathed Sword: The Royal Marines and Amphibious Warfare in the Interwar Years - A Passive Response, in: The Journal of Military History 55:3 (1991), S. $345-364$.

Black, Jeremy. Imperial Legacies. The British Empire Around the World. New York 2019.

Calder, Alex: A Head for Numbers: Alexander Aitken at Gallipoli and the Somme, in: Journal of New Zealand Literature: JNZL, 33:2 (2015), New Zealand and the First World War, S. $108-123$.

Cameron, David; Donlon, Denise: A Preliminary Archaeological Survey of the ANZAC Gallipoli Battlefields of 1915, in: Australasian Historical Archaeology 23 (2005), S. 131-138.

Campbell, John P.: Refighting Britain's Great Patriotic War, in: International Journal 26:4 (1971), S. $686-705$.

Çandar, Cengiz: Atatürk's Ambiguous Legacy, in: The Wilson Quarterly 24: 4 (2000), S. 88-96. Carlyon, Leslie Allen: Gallipoli. London et al. 2003.

Cassar, George H.: The French and the Dardanelles: A Study of Failure in the Conduct of War. London 1971.

Churchill, Winston S.: A Roving Commission. My Early Life. New York 1930.

Churchill, Winston S.: The World Crisis. Toronto 1923.

Ciddi, Sinan: Kemalism in Turkish Politics: The Republican People's Party, Secularism and Nationalism. London 2009.

Çinar, Alev: Modernity, Islam, and Secularism in Turkey: Bodies, Places, and Time. Minneapolis, MN 2005.

Cochet, François: L'armée d'Orient, des expériences combattantes loin de Verdun, in: Cahiers de la Méditerranée 81 (2010), S. 91-103.

Colles, Ted: Beachy, in: The Anzac Book. Written and Illustrated in Gallipoli by the The Men of Anzac. London et al. 1916, S. 35-40. 
Cooper, Bryan. The Tenth (Irish) Division in Gallipoli. London 1918.

Daley, Paul. Turkish Islamist Push May be to Blame for Removal of Atatürk Inscription at Anzac Cove, in: The Guardian, 16. Juni 2017, https://www.theguardian.com/world/2017/jun/16/ turkish-islamist-push-may-be-to-blame-for-removal-of-ataturk-inscription-at-anzac-cove. (10.06.2018).

Dardanelles Commission: First Report. London 1917.

Dardanelles Commission: The Final Report. London 1919.

Deygas, F.-J.: L’Armée d'Orient dans la guerre mondiale. Paris 1932.

Dincsahin, Sakir. State and Intellectuals in Turkey: The Life and Times of Niyazi Berkes, 1908-1988. Lanham, MD 2015.

Doyle, Peter / Bennett, Matthew R.: Military Geography: The Influence of Terrain in the Outcome of the Gallipoli Campaign, 1915, in: The Geographical Journal 165:1 (1999), S. $12-36$.

Dutton, David: „Docile Supernumerary“. A French Perspective on Gallipoli, in: Macleod, Jenny (Hg.): Gallipoli. Making History, London/New York 2004, S. 86-97.

Erickson, Edward J.: Gallipoli: Command Under Fire. London 2015.

Erickson, Edward J.: Strength against Weakness: Ottoman Military Effectiveness at Gallipoli, 1915, in: The Journal of Military History 65:4 (2001), S. 981-1011.

Erickson, Edward J.: The Turkish Official Military Histories of the First World War: A Bibliographic Essay, in: Middle Eastern Studies 39:3 (2003), S. 190-198.

Ewing, William: From Gallipoli to Baghdad. London / New York / Toronto 1917.

Fewster, Kevin; Başarin, Vecihi; Hürmüz Başarin, Hatice: Gallipoli. The Turkish Story. Crows Nest ${ }^{2} 2003$.

Findley, Carter V.: Turkey, Islam, Nationalism, and Modernity: A History, 1789-2007. New Haven, CT 2010.

Fleet, Kate: Early Turkish Naval Activities, in: Oriente Moderno 81:1 (2001), The Ottomans and the Sea, S. $129-138$.

Frances, Raelene / Scates, Bruce (Hrsg.): Beyond Gallipoli. New Perspectives on Anzac. Clayton 2016.

Garland, H. G.: My Lady Nicotine, in: The Anzac Book. Written and Illustrated in Gallipoli by the The Men of Anzac. London et al. 1916, S. 142-143.

Gerlach, Christian. Extrem gewalttätige Gesellschaften. Massengewalt im 20. Jahrhundert. München 2011

Gillam, Major John Graham: Gallipoli Diary. London 1918.

Grüßhaber, Gerhard: The German Spirit in the Ottoman and Turkish Army, 1908-1938: A History of Military Knowledge. Berlin 2018.

Hamilton, Ian: Gallipoli Diary, 2 Bde. London 1920.

Hanioğlu, M. Şükrü: Ataturk: An Intellectual Biography. Princeton, NJ 2011.

Hart, Peter: Gallipoli. Oxford / New York 2011.

Heberlein, Wolf: Kemal Atatürk, in: Zeitschrift für Politik 27:3 (1937), S. 168-172.

Hoffenberg, Peter H.: Landscape, Memory and the Australian War Experience, 1915-18, in: Journal of Contemporary History 36:1 (2001), S. 111-131.

Hopkins-Weise, Jeff: Blood Brothers: The Birth of the ANZACS, London 2009.

Ihrig, Stefan: Atatürk in the Nazi Imagination. Cambridge, MA 2014.

Jauffret, Jean-Charles: Gallipoli. A French Perspective, in: Army Quarterly and Defence Journal 126:4 (1996), S. $466-474$. 
Jauffret, Jean-Charles: Gallipoli. A French Perspective - Part 2, in: Army Quarterly and Defence Journal 127:1 (1997), S. 93-101.

Johnson, Boris. Der Churchill-Faktor. Stuttgart 2015.

Kannengießer, Hans: Gallipoli. Bedeutung und Verlauf der Kämpfe 1915. Wolfenbüttel 2012 (Berlin 1927).

Kelkit, Abdullah / Celik Sezgin / Eşbah, Hayriye: Ecotourism Potential of Gallipoli Peninsula Historical National Park, in: Journal of Coastal Research 26:3 (2010), S. 562-568.

Kellerhoff, Sven Felix. „Diese Argumentation ist grobschlächtig-polemisch und schrecklich einseitig“, in: Welt Online, 4. Februar 2020, https://www.welt.de/geschichte/ article205844535/Kriegsausbruch-1914-Diese-Argumentation-ist-grobschlaechtigpolemisch.html (08.08.2020).

Kennan, George F.: The Decline of Bismarck's European Order. Franco-Russian Relations, 1875-1890, Princeton 1979.

Kezer, Zeynep: Building Modern Turkey: State, Space, and Ideology in the Early Republic. Pittsburgh, PA 2015.

Kirişci, A. Candan. The Face of the 'Enemy': The Image of the Adversary in Turkish Literary Works about Gallipoli, in: Journal of New Zealand Literature: JNZL 33 (2015), Part 2: New Zealand and the First World War, S. 160-181.

Krethlow, Carl Alexander. Bagdad 1915/17. Weltkrieg in der Wüste, Paderborn 2018.

Le Naour, Jean-Yves: 1915. L'enlisement. Paris 2013.

MacGregor, David: The Use, Misuse, and Non-Use of History: The Royal Navy and the Operational Lessons of the First World War, in: The Journal of Military History 56:4 (1992), S. $603-616$.

MacKenzie, Compton: Gallipoli Memories. New York 1930.

Macleod, Jenny: Britishness and Commemoration. National Memorials to the First World War in Britainand Ireland, in: Journal of Contemporary History 48:4 (2013), S. 647-665.

Macleod, Jenny: Gallipoli, Oxford / New York 2015.

Macleod, Jenny: Reconsidering Gallipoli. Manchester / New York 2004.

Mango, Andrew: From the Sultan to Atatürk: Turkey. London 2010.

Masefield, John: Gallipoli. New York 1916.

McCartney, Richard Hayes: Gallipoli. New York o. J. [vermutlich 1916].

McMeekin, Sean: World War I and the Establishment of the Republic, in: Heper, Metin / Sayari, Sabri (Hrsg.): The Routledge Handbook of Modern Turkey. London 2012, S. $35-43$.

Monro, J. S.: At Gallipoli, in: The British Medical Journal 2:5462 (1965), S. 648.

Moore, Robert C. Die deutsche Legende vom ,aufgezwungenen Verteidigungskrieg، 1914, in: Historische Zeitschrift 309:3 (2019), S. 606-658.

Moorehead, Alan Gallipoli. New York 2002 (1956).

Jacques Mordal, L'Expédition des Dardanelles 5 Novembre 1915 - 9 Janvier 1916, in: Revue Historique de l'Armée 21:2 (1965), S. 27-48.

Mühlmann, Carl: Der Kampf um die Dardanellen, Schlachten des Weltkrieges, Bd. 16. Oldenburg i. O. / Berlin 1927.

Music in Gallipoli, in: The Musical Times 57:884 (1916), S. 458 und 464.

Navaro-Yashin, Yael: Faces of the State: Secularism and Public Life in Turkey. Princeton, NJ 2002.

Neitzel, Sönke: Kriegsausbruch. Deutschlands Weg in die Katastrophe 1900-1914. Zürich 2002. 
Nesbit, Cecilia: A Call from Gallipoli, Reprint from The Advertiser, Adelaide 1915.

Ökten, Nazlı: An Endless Death and Eternal Mourning, in: Özyürek, Esra (Hrsg.): The Politics of Public Memory in Turkey. Syracuse, NY 2007, S. 95-113.

Özakman, Turgut: Dirilis: Canakkale 1915. Ankara 2014.

Ozdemir, Hikmet: The Ottoman Army 1914-1918: Disease and Death on the Battlefield, Salt Lake City, UT 2008.

Özkirimli, Umut: The Changing Nature of Nationalism in Turkey: Actors, Discourses, and the Struggle for Hegemony, in: Kadioglu, Ayse / Keyman, E. Fuat (Hrsg.): Symbiotic Antagonisms: Competing Nationalisms in Turkey. Salt Lake City, UT 2011, S. 82-100.

Özyürek, Esra: Miniaturizing Atatürk: Privatization of State Imagery and Ideology in Turkey, in: American Ethnologist 31:3 (2004), S. 374-391.

Özyürek, Esra: Nostalgia for the Modern: State Secularism and Everyday Politics in Turkey. Durham 2006.

Palmer, Alan: The Gardeners of Salonika. The Macedonian Campaign 1915-1918. London 1965.

Patel, Samir S.: Anzac's Next Chapter, in: Archaeology 66:3 (2013), S. 53-54, 56, 58, 60.

Perk, Kadri. Çanakkale Savaşları Tarihi, 3 Bde. İstanbul 1940.

Prigge, Erich R.: Gallipoli: Der Kampf um den Orient, von einem offizier aus dem Stabe des Marschalls Liman von Sanders. Berlin 1916.

Prior, Robin: Gallipoli. The End of the Myth. New Haven, CT / London 2009.

Pugsley, Christopher: Gallipoli: The New Zealand Story. Auckland 2016.

Rechniewski, Elizabeth: Quand l'Australie invente et réinvente une tradition: L'exemple du débarquement de Gallipoli (Avril 1915), in: Vingtième Siècle. Revue d'histoire 101 (2009), S. $123-132$.

Reynolds, Michael A.: Shattering Empires: The Clash and Collapse of the Ottoman and Russian Empires 1908-1918. Cambridge 2011.

Richter, Heinz A.: Der Krieg im Südosten, Bd. 1: Gallipoli 1915, Peleus. Studien zur Archäologie und Geschichte Griechenlands und Zyperns; Bd. 65. Ruhpolding 2013.

Rudenno, Victor: Gallipoli. Attack from the Sea. New Haven, CT / London 2008.

Sagona, Antonio; Atabay, Mithat; Mackie, C. J.; McGibbon, Ian; Reid, Richard (Hrsg.): ANZAC Battlefield. A Gallipoli Landscape of War and Memory. Melbourne 2016.

Sagona, Antonio; Mackie, C. J.: Introduction, in: Sagona, Antonio; Atabay, Mithat; Mackie, C. J.; McGibbon, Ian; Reid, Richard (Hrsg.): ANZAC Battlefield. A Gallipoli Landscape of War and Memory. Melbourne 2016, S. 1-3.

Sanders, Liman von: Fünf Jahre Türkei. Berlin 1920.

Schiavon, Max: Front d’Orient. Du désastre des Dardanelles à la victoire finale, 1915-1918. Paris 2014.

Schmidt, Rainer F.: „Revanche pour Sedan“ - Frankreich und der Schlieffenplan. Militärische und bündnispolitische Vorbereitung des Ersten Weltkriegs, in: Historische Zeitschrift 303 (2016), S. 393-425.

Schoen, Walter von: Die Hölle von Gallipoli. Der Heldenkampf an den Dardanellen. Berlin 1937.

Smith, George L.: My Anzac Home, in: The Anzac Book. Written and Illustrated in Gallipoli by the The Men of Anzac. London et al. 1916), S. 107.

Sohail, Khalid. Prophets of Violence - Prophets of Peace: Understanding the Roots of Contemporary Political Violence. Whitby 2005. 
Somay, Bülent: The Psychopolitics of the Oriental Father: Between Omnipotence and Emasculation. London 2014.

Taussig, Mick: An Australian Hero, in: History Workshop 24 (1987), S. 111-133.

Tetik, Ahmet (Hrsg.): Sofya Askerî Ataşesi Mustafa Kemal'in Raporları, Kasım 1913-Kasım 1914. Ankara 2007.

The Anzac Book. Written and Illustrated in Gallipoli by the The Men of Anzac. London et al. 1916.

Travers, Tim: Command and Leadership Styles in the British Army. The 1915 Gallipoli Model, in: Journal of Contemporary History 29:3 (1994), S. 403-442.

Travers, Tim: Gallipoli 1915. Stroud ${ }^{3} 2004$.

Travers, Tim: Liman von Sanders, the Capture of Lieutenant Palmer, and Ottoman Anticipation of the Allied Landings at Gallipoli on 25 April 1915, in: The Journal of Military History 65:4 (2001), S. 965-979.

Travers, Tim / Celik, Birten: „Not One of Them Ever Came Back“. What Happened to the 1/5 Norfolk Battalion on 12 August 1915 at Gallipoli? in: The Journal of Military History 66:2 (2002), S. $389-406$.

Ulrichsen, Kristian Coates: The First World War in the Middle East. London 2014.

Üngör, Ugur Ümit: The Making of Modern Turkey: Nation and State in Eastern Anatolia, 1913-1950. Oxford 2011.

Uyar, Mesut. Remembering the Gallipoli Campaign: Turkish Official Military Historiography,

War Memorials and Contested Ground, in: First World War Studies 7:2 (2016), S. 165-191.

Uzuner, Buket: Uzun Beyaz Bulut: Gelibolu. Istanbul 2001.

Vassal, Joseph: Dardanelles, Serbie, Salonique. Impressions et souvenirs de guerre (avril 1915 - février 1916). Paris 1916.

Virgili, Fabrice: L'Australian War Memorial à Canberra, in: Vingtième Siècle. Revue d'histoire 101 (2009), S. $197-200$.

Vogel, Ezra F.: Nation Rebuilders: Mustafa Kemal Atatürk, Lee Kuan Yew, Deng Xiaoping, and Park Chung Hee, in: Kim, Byung-Kook / Vogel, Ezra F. (Hrsg.), The Park Chung Hee Era. Cambridge, MA 2011, S. 513-541

Wagner, Kim. Imperial Legacies by Jeremy Black Review - Whitewash for Britain's Atrocities, in: The Guardian, 10. August 2019, https://www.theguardian.com/books/2019/aug/10/ imperial-legacies-jeremy-black-review-empire-multiculturalism (12.08.2019).

Weiker, Walter F.: Atatürk as a National Symbol, in: Turkish Studies Association Bulletin 6:2 (1982), S. 1-6.

West, Brad: Enchanting Pasts. The Role of International Civil Religious Pilgrimage in Reimagining, in: Sociological Theory 26:3 (2008), S. 258-270.

Wilson, Christopher S.: Representing National Identity and Memory in the Mausoleum of Mustafa Kemal Atatürk, in: Journal of the Society of Architectural Historians 68:2 (2009), S. $224-253$.

Wilson, Janet: „Colonize. Pioneer. Bash and Slash“: Once on Chunuk Bair and the Anzac Myth, in: Journal of New Zealand Literature 34:1 (2016), S. 27-53.

Winter, Jay: Cultural Divergences in Patterns of Remembering the Great War in Britain and France, in: Tombs, Robert / Chabal, Emile (Hrsg.): Britain and France in Two World Wars. Truth, Myth and Memory. London / New York 2013, S. 161-178.

Wolf, Klaus. Gallipoli 1915. Das deutsch-türkische Militärbündnis im Ersten Weltkrieg, Bonn 2008. 
Yavuz, M. Hakan: Islamic Political Identity in Turkey. Oxford 2003.

Zürcher, Erik-Jan: In the Name of the Father, the Teacher and the Hero: The Atatürk Personality Cult in Turkey, in: Ibrahim, Vivian / Wunsch, Margit (Hrsg.): Political Leadership, Nations and Charisma. London 2012, S. 129-142. 
